\title{
Pengembangan Media Komik Digital Materi Virus Terintegrasi Nilai Islam Di MAN Kota Palangka Raya
}

\author{
Latifah Nor Thoybah*, Mukhlis Rohmadi, Nanik Lestariningsih \\ Program Studi Tadris Biologi, Jurusan Pendidikan MIPA, \\ Fakultas Tarbiyah dan Ilmu Keguruan, Institut Agama Islam Negeri Palangka Raya \\ Email: lathifahnortyohbah@gmail.com
}

\begin{abstract}
ABSTRAK
Pembelajaran pada era revolusi industri 4.0 identik dengan perkembangan ilmu pengetahuan dan teknologi salah satunya nmenggunakan media berbasis digital diantaranya memberikan visualisasi berupa komik digital. Penelitian ini bertujuan untuk mengetahui: (1) Profil dari media komik digital terintegrasi nilai islam materi virus di MAN Kota Palangka Raya; (2) Validitas dari ahli tentang media komik digital terintegrasi nilai islam materi virus di MAN Kota Palangka Raya dan; (3) Kepraktisan media komik digital terintegrasi nilai islam materi virus di MAN Kota Palangka Raya yang telah dikembangkan; dan (4) Efektivitas media komik digital terintegrasi nilai islam materi virus di MAN Kota Palangka Raya. Penelitian ini menggunakan metode Research and Development (R\&D) dengan Model ADDIE, tahapan dari penelitian ini daintaranya analisis, desain, pengembangan. Hasil penelitian ini adalah; 1) profil media komik digital yang dikembangkan yaitu berbasis aplikasi Flip PDF, berisi materi biologi Virus, serta memuat integrasi nilai Islam; 2) berdasarkan penilaian ahli media diperoleh persentase 98\% dengan kriteria sangat baik. Hasil penilaian ahli materi diperoleh persentase 99\% dengan kriteria sangat baik. Hasil penilaian ahli materi integrasi nilai islam diperoleh persentase 100\% dengan kriteria sangat baik. Hasil uji coba kelompok kecil diperoleh persentase 91,3\% dengan kriteria sangat baik; 3) hasil kepraktisan sangat positif terhadap pengembangan komik digital ini sebagai media untuk peserta didik belajar; (4) hasil uji efektifitas diperoleh 91,3\% dengan kriteria sangat baik.
\end{abstract}

Kata Kunci: komik digital, biologi, virus, integrasi nilai islam

\begin{abstract}
ABSTRAC
Learning in the era of the industrial revolution 4.0 is identical to the development of science and technology, one of which is using digital-based media including providing visualization in the form of digital comics. This study aims to determine: (1) The profile of digital comic media integrated Islamic values in virus materials in MAN Palangka Raya City; (2) Validation of digital comic media integrated Islamic values in virus materials in MAN Palangka Raya City and; (3) The practicality of teachers and students regarding the validation of digital comic media integrated Islamic values in virus materials in MAN Palangka Raya City that have been developed; and (4) The effectiveness of digital comic media integrated with Islamic values of viral material in MAN Palangka Raya City. This study uses the Research and Development (R\&D) method with the ADDIE Model, which stages is analysis, design, development. The results of this study are; 1) The digital comic media profile is based on the Flip PDF application contains integrated Islamic values in Virus material 2) based on the media expert's assessment, it was obtained a percentage of $98 \%$ with very good criteria. The results of the material assessment obtained a percentage of $99 \%$ with very good criteria. The results of the assessment of the value of Islamic integration obtained a percentage of $100 \%$ with very good criteria. The results of the small group trial obtained a percentage of $91.3 \%$ with very good criteria; 3$)$ The practically are very positive towards the development of digital comics as a medium for students to learn; (4) the results of the effectiveness test obtained $91.3 \%$ with very good criteria.
\end{abstract}

Keywords: digital comics, biology, viruses, Islamic values integration

PENDAHULUAN

Proses pembelajaran menurut Sudjana

(2010) merupakan proses belajar mengajar atau proses pengajaran merupakan suatu kegiatan melaksanakan kurikulum dengan mencapai tujuan pendidikan yang ditetapkan. 


\section{JPSP: Jurnal Penelitian Sains dan Pendidikan}

https://e-journal.iain-palangkaraya.ac.id/index.php/mipa/

Proses pembelajaran dapat dikatakan efektif jika tujuan pembelajaran terlaksana yakni pemahaman peserta didik pada materi.

Pada Era Revolusi Industri 4.0 Proses pembelajaran sangat identik dengan perkembangan ilmu pengetahuan dan teknologi yang bertujuan membangun sumber daya profesional, unggul dan berdaya saing tinggi. Proses pendidikan tidak dapat dipisahkan dari proses pembangunan yang diarahkan dan bertujuan untuk membangun sumber daya manusia yang berkualitas. Menurut Widaningsih (2019), lahirnya Era Industri 4.0 dapat menjadi tantangan besar untuk mengahasilkan sumber daya manusia yang berkarakter dan mampu berkompetisi dalam bidang teknologi. Salah satu solusi dalam penyelarasan proses pembelajaran dan kemajuan teknologi tersebut adalah dapat dengan menggunakan media yang berbasis digital.

Media yang menyenangkan merupakan media yang dapat memberikan deskripsi langsung dan berpengaruh terhadap mental atau dapat dikatakan menyenangkan untuk dapat dipergunakan seperti yang disebutkan dalam penelitian Rudy dan Hibiyatul (2017) karena aktivitas pembelajaran melibatkan minat dan mental peserta didik dengan memberikan media yang menyenangkan. Diantaranya bisa dengan memberikan visualisasi berupa komik digital.

Komik digital merupakan salah satu media pembelajaran yang juga dapat diterapkan bagi peserta didik yang kesulitan untuk dapat mendeskripsikan suatu objek hanya berdasarkan teks dan juga merupakan sarana yang memiliki kegunaan praktis karena berbasis digital. Menurut Rudy (2017) komik merupakan sebuah gagasan ide cerita yang dituangkan dalam bentuk gambar. Yang mana komik dapat menyalurkan energi yang berpengaruh terhadap pengalaman belajar.

Pengalaman belajar akan lebih baiknya jika disisipkan dengan keimanan dan wawasan spiritual. Dilihat dari tujuan lembaga yang menjadi objek penelitian ini yaitu MAN Kota Palangka Raya yang merupakan sekolah berbasis islam, maka peneliti mengembangkan bahan ajar berbasis komik digital terintegrasi nilai islam. Komik ini sengaja dirancang atau dikembangkan oleh peneliti agar produk pengembangan nantinya sesuai dengan visi atau tujuan dari lembaga serta dapat mengetahui dan menerapkan nilai-nilai islam sesuai materi diajarkan kepada peserta didik.

Berdasarkan hasil angket yang disebar di 24 peserta didik dapat diketahui bahwa: 1) $29.1 \%$ Peserta didik memiliki buku pegangan lain dalam mempelajari sub materi virus; 2) $83,3 \%$ Sedang mencari bahan selain buku dari sekolah; 3) 91,6\% Merasa kesulitan dalam mempelajari sub materi virus; 4) $75 \%$ pernah diberikan media khusus dari guru (ppt, video, alat peraga); 5) 8,3\% Pernah diajak guru praktikum mengenai virus; 6) $41,6 \%$ merasa terbantu mempelajari virus karena ketersediaan laboratorium dan perpustakaan; 7) 41,6\% antusias dalam mengikuti pembelajaran sub materi virus; 8) 58,3\% Masih mengalami kesulitan dengan media pembelajaran yang telah diberikan guru; 9) 95,8\% Membutuhkan media belajar alternatif yang mudah dan menarik untuk mempelajari virus; dan 10) 
https://e-journal.iain-palangkaraya.ac.id/index.php/mipa/

95,8\% Setuju untuk diadakannya media pembelajaran berupa komik terintegrasi nilai islam untuk dapat mempermudah pembelajaran mengenai virus dan meningkatkan wawasan spiritual.

Tujuan lembaga yang menjadi objek penelitian ini yaitu MAN Kota Palangka Raya yang merupakan sekolah yang berbasis islam. Berdasarkan (Rofi'I, Mulyono, Lestariningsih dan Ayatusa'adah, 2017) Pengembangan sarana madrasah berupa buku ajar biologi terintegrasi nilai islam dirasa perlu. Hal ini karena madrasah merupakan hasil perkembangan dari pesantren yang memusatkan kegiatannya untuk mendalami ilmu agama, maka peneliti pengembangkan bahan ajar komik berbasis digital yang terintegrasi nilai islam. Komik ini sengaja dirancang atau dikembangkan oleh peneliti agar produk pengembangan nantinya sesuai dengan visi atau tujuan dari lembaga serta dapat mengetahui dan menerapkan nilai-nilai islam sesuai materi yang diajarkan kepada peserta didik.

Berdasarkan uraian di atas untuk mengatasi masalah keaktifan dan pemahaman belejar peserta didik mengenai materi abstrak di MAN Kota Palangka Raya. Pengembang mencoba mengembangkan produk berupa komik digital pada materi virus yang terintegrasi nilai islam. Diharapkan melalui produk ini, proses pembelajaran peserta didik dapat lebih aktif dan meningkatkan semangat belajar pada materi yang bersifat abstrak.

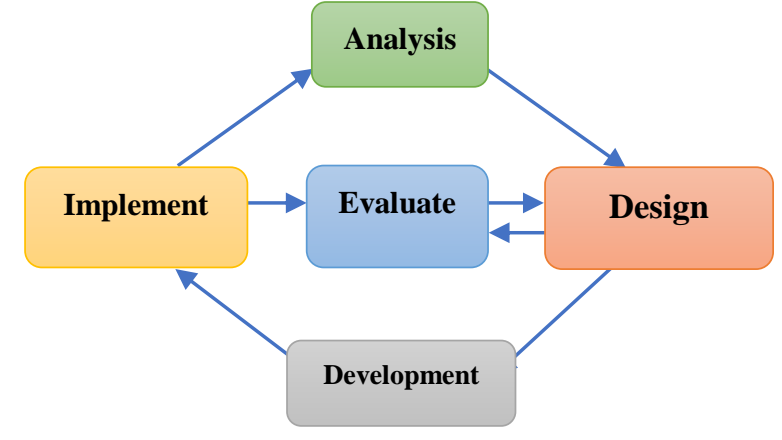

Gambar Error! No text of specified style in

document..1 Tahapan model Pengembangan ADDIE (Sugiyono,2019)

1. Analysis

Melakukan analisis kebutuhan dengan teknik survey menggunakan instrumen berupa angket, wawancara dan observasi di MAN Kota Palangka Raya untuk mengetahui potensi dan masalah. Kebutuhan ini dijaring dengan berbagai teknik dari lapangan, seperti wawancara, observasi, dan mungkin kebutuhan dan angket peserta didik

2. Design

Desain merupakan tahap pembuatan kerangka produk dari awal 


\section{JPSP: Jurnal Penelitian Sains dan Pendidikan}

https://e-journal.iain-palangkaraya.ac.id/index.php/mipa/

hingga akhir. Dimulai dengan

menganalisis kompetensi dasar dan

indicator materi virus, selanjutnya

mengembangkan ide (brain storming).

Kemudian membuat konsep dari materi

berupa storyboard. Yang nantinya storyboard ini akan menjadi rancang bangun dari produk komik yang akan dikembangkan.

3. Development

Setelah produk selesai dibuat, produk akan divalidasi oleh ahli, direvisi sesuai saran ahli, kemudian dilakukan uji coba skala kecil dan direvisi lagi sesuai saran pemakai.

a. Validasi Produk

Validasi produk merupakan kegiatan untuk menilai produk yang berupa media komik terintegrasi nilai islam pada materi virus. Media ini divalidasi dan dievaluasi, dinilai layak atau tidak untuk diterapkan sebagai media dalam kegiatan pembelajaran biologi materi virus di MAN Kota Palangka Raya. Validasi dilakukan oleh ahli materi dan ahli media.

b. Revisi Produk

Setelah bahan ajar divalidasi serta mendapatkan komentar maupun saran dari validator mengenai kelebihan serta kekurangan bahan ajar yang dikembangkan. Kemudian, komentar dan saran dari para ahli tersebut dijadikan sebagai dasar untuk melakukan revisi baik dari aspek isi, penyajian, bahasa dan desain media. Setelah dilakukan revisi, kemudian produk tersebut divalidasi kembali oleh para ahli sampai dinyatakan valid dan dapat digunakan pada skala kecil.

c. Uji Coba Skala Kecil

Setelah produk dinyatakan valid, selanjutnya media tersebut diujicobakan pada lingkup terbatas. Uji coba produk skala kecil diterapkan pada kelompok kecil yang terdiri dari 6 peserta didik semester ganjil kelas $\mathrm{X}$ MAN Kota Palangka Raya program studi Tadris Biologi IAIN Palangka Raya dan 1 orang guru biologi. Hal ini dilakukan untuk menentukan kepraktisan dan efektifitas produk tersebut. Data kepraktisan diperoleh dengan menggunakan angket respon dosen dan mahasiswa, serta observasi keterterapan. Sedangkan data efektifitas diperoleh dengan menggunakan soal tes terintegrasi islam. Hasil penilaian, komentar dan saran, serta pernyataan dari responden dan observer menjadi dasar untuk melakukan revisi produk.

\section{HASIL DAN PEMBAHASAN}

1. Pembahasan Profil Komik Digital

Komik yang dikembangkan dalam bentuk digital berbasis Flip pdf yang dapat diaplikasikan pada laptop maupun smartphone yang dapat diakses melalui link https://online.fliphtml5.com/ilxab/xtzv/.

Selain itu menimbang dari lembaga yang akan dijadikan sebagai sarana penelitian merupakan sekolah berbasis Islam komik ini disisipkan beberapa integrasi islam di dalamnya. 


\section{JPSP: Jurnal Penelitian Sains dan Pendidikan}

https://e-journal.iain-palangkaraya.ac.id/index.php/mipa/

Komik ini berjudul "Virus Terintegrasi Islam”, yang berlatarkan sebuah sekolah Madrasah Aliyah. Tokoh dari komik ini murni hanya fiksi dan tidak diambil dari kejadian nyata. Dalam penokohan. Pengembang mengambil tokoh 3 santri dan seorang guru sesuai dengan target pembaca yang mana merupakan anak Madrasah Aliyah, antara lain yaitu Aldo, Ucup, Alya dan Pak Ustad.

Plot pada komik ini ada 3 bagian yaitu pembuka, materi (inti) dan penutup. Pada bagian pembuka diceritakan seorang peserta didik bernama Aldo yang bermain game zombie. Pengembang sengaja mengambil cerita ini sebagai pembuka karena banyak pemuda sekarang yang mengetahui virus melalui game tidak kontekstual. Sehingga pemikiran dan gambaran mereka mengenai virus sedikit tercampur oleh teori fiksional dari game tersebut. Kemudian beralih kebagian inti. Disini diberikan penjabaran materi virus dan juga peleraian masalah yang mana masalahnya adalah ketidakpahaman Aldo dan Ucup mengenai konsep virus yang sebenarnya sehingga tokoh Alya dan Pak Ustad menjadi sosok yang meluruskan pemahaman mereka. Pada bagian penutup sendiri akhirnya Aldo dan Ucup dapat memahami sekaligus menyadari kekuasaan Allah SWT mengenai Virus.

Pada materi komik terdapat beberapa indikator pembelajaran yang diambil berdasarkan kompetensi inti dan dasar yaitu antara lain; 1) Mengidentifikasi ciri-ciri Virus; 2) Mengetahui ciri benda mati virus; 3) Mengetahui ciri hidup virus;

4) Mengidentifikasi peran virus; 5) Mengetahui Peran virus yang menguntungkan; 6) Mengetahui peran virus yang merugikan. Dari beberapa indikator tersebut pengembang mengembangkan konsep cerita dan integrasi ayat Alquran yang selaras dengan jalannya cerita komik.

Komik ini sendiri dirancang memiliki 54 halaman termasuk cover dengan ukuran file 29,385 Kilo byte. Perangkat lunak yang digunakan dalam pengembangan komik ini antara lain adalah word office, photoshop CS 5, Medibang paint, dan flip page.

Pengembangan komik ini diawali dengan penentuan mengenai tokoh, alur dan setting komik. Materi pembelajaran serta tafsir ayat yang akan di sisipkan juga perlu di olah dan dipertimbangkan terlebih dahulu agar kompetensi inti dan ayat Alquran mengenai materi virus dapat selaras dengan alur cerita komik. Jika gagasan awal telah dibayangkan. Pengembang mulai mendesain name (storyboard gambar kasar), name dapat dilihat pada gambar 4.11. Name berfungsi agar pengembang dapat menentukan posisi karakter, tata letak, sudut pandang serta serta latar dari panel komik.

Setelah kerangka dari komik jadi, pembuatan komik dilanjutkan dengan pembuatan sketsa tokoh dan latar Dalam proses ini pengembang menggunakan aplikasi Medibang paint pada handphone android dengan jari (tanpa stylus) . Pada tahap sketsa juga pengembang menyusun 


\section{JPSP: Jurnal Penelitian Sains dan Pendidikan}

https://e-journal.iain-palangkaraya.ac.id/index.php/mipa/

panel, balon text dan penokohan agar komik dapat lebih mudah dipahami oleh pembaca. Jika proses sketsa telah selesai. Komik kemudian dilanjutkan dengan proses lineart dan coloring. Lineart merupakan garis bersih pada gambar komik, sedangkan coloring merupakan tahap pewarnaan. Pada tahap ini masih menggunakan aplikasi Medibang paint dan dibutuhkan waktu yang lebih lama karena diperlukan ketelitian dan kerapian agar gambar nampak bersih.

Beralih dari proses gambar, file gambar yang sudah jadi dalam format Jpg. Dipindahkan ke laptop dan diedit kembali. Proses ini disebut juga dengan istilah editing. Dalam proses ini pengembang menggunakan aplikasi Photoshop CS 5 yang mana proses ini meliputi pembuatan panel, balon text serta tulisan lain. Setelah semuanya selesai, proses tersebut diedit kembali pada aplikasi word office untuk diberi margin dan nomor halaman, yang mana disini komik di jadikan sebuah buku dengan berbentuk format pdf. Setelah semua prosedur selesai komik tersebut di masukan ke dalam aplikasi Flip PDF sebagai agar nampak efek seperti sedang membaca buku.

Berdasarkan penelitian yang telah dilakukan, media komik ini memiliki kelebihan yaitu dapat digunakan online maupun offline sehingga dapat menjadi solusi untuk pembelajaran online di masa Covid- 19 seperti sekarang. Komik ini juga bisa meningkatkan minat baca sehingga kegiatan pembelajaran menjadi menarik dan menyenangkan. Selain itu, kelebihan dari komik yang dibuat ini adalah tidak hanya dapat digunakan dengan laptop atau komputer saja, tetapi juga menggunakan smartphone. Selain dari segi media, komik ini juga memuat uraian integrasi Islam yang terkait dengan materi dan proses pembelajaran, adanya informasi tentang ilmuwan-ilmuwan serta informasi mengenai virus covid-19. Selain memiliki kelebihan, komik ini juga memiliki kekurangan. Pada penelitian pengembangan ini kekurangannya yaitu hanya berisi satu materi saja yang dibahas.

2. Pembahasan Hasil dan Tanggapan Validator

Penilaian komik digital dilakukan melalui beberapa tahap validasi yaitu validasi ahli media, validasi ahli materi biologi, dan validasi ahli integrasi Islami. Hal ini dilakukan agar media komik dapat diperbaiki dan disempurnakan sebelum dilakukannya uji coba langsung kepada peserta didik.

Proses validasi yang pertama adalah validasi media. Proses ini dilakukan dengan menyerahkan angket kepada 2 dosen biologi Fakultas Tarbiyah dan Ilmu Keguruan (FTIK) IAIN Palangka Raya. Hasil penilaian validasi media dilakukan melalui dua tahap pada masing-masing ahli yang mana menghasilkan penilaian yang berbeda pada tiap tahapnya. Tahap pertama validasi media terhadap media komik diperoleh persentase sebesar $89 \%$ dengan kriteria sangat layak/valid. Pada proses tahap pertama didapatkan saran dari masing masing validator untuk dapat memperbaiki 


\section{JPSP: Jurnal Penelitian Sains dan Pendidikan}

https://e-journal.iain-palangkaraya.ac.id/index.php/mipa/

media komik terlebih dahulu meliputi, perbaikan sampul, perbaikan gambar integrasi ayat, perbaikan gambar yang blur dan tidak jelas dan penulisan huruf asing dan typo lainnya. Setelah saran dari tahap pertama telah diperbaiki. Kemudian dilakukan uji kembali pada tahap kedua. Pada tahap kedua validasi media hasil penilaian memperoleh persentase sebesar 99\% dengan kriteria sangat layak. Pada tahap kedua sudah tidak ada perbaikan yang mana media komik telah layak dan dapat diuji cobakan dari segi media.

Penilaian ahli materi dilakukan oleh 2 validator ahli materi yaitu dosen biologi Fakultas Tarbiyah dan Ilmu Keguruan (FTIK) IAIN Palangka Raya. Hasil penilaian validasi materi dilakukan melalui dua tahap pada masing-masing ahli yang mana menghasilkan penilaian yang berbeda pada tiap tahapnya. Tahap pertama validasi media terhadap media komik diperoleh persentase sebesar 92\% dengan kriteria sangat layak/valid. Pada proses tahap pertama didapatkan saran dari masing masing validator untuk dapat memperbaiki media komik terlebih dahulu. Saran yang diberikan diantaranya adalah perlu ditambahkan materi covid-19 dan cara penanggulangannya, memperjelas deskripsi materi serta menambahkan soal latihan. Setelah saran dari tahap pertama telah berhasil direvisi. Kemudian dilakukan uji kembali pada tahap kedua. Pada tahap kedua validasi media hasil penilaian memperoleh persentase sebesar 98\% dengan kriteria sangat layak. Pada tahap kedua sudah tidak ada perbaikan yang mana media komik telah layak dan dapat diuji cobakan dari segi materi.

Penilaian lainnya adalah dari ahli integrasi islam dengan validator dosen Fakultas IAIN Palangka Raya. Hasil penilaian ahli tentang integrasi nilai islam diperoleh persentase sebesar $100 \%$ dengan kriteria sangat layak/valid, sehingga dari hasil validasi ini, komik media telah layak untuk di uji cobakan. Secara keseluruhan hasil validasi pada tahap 1 dan 2 dapat dilihat pada gambar diagram berikut

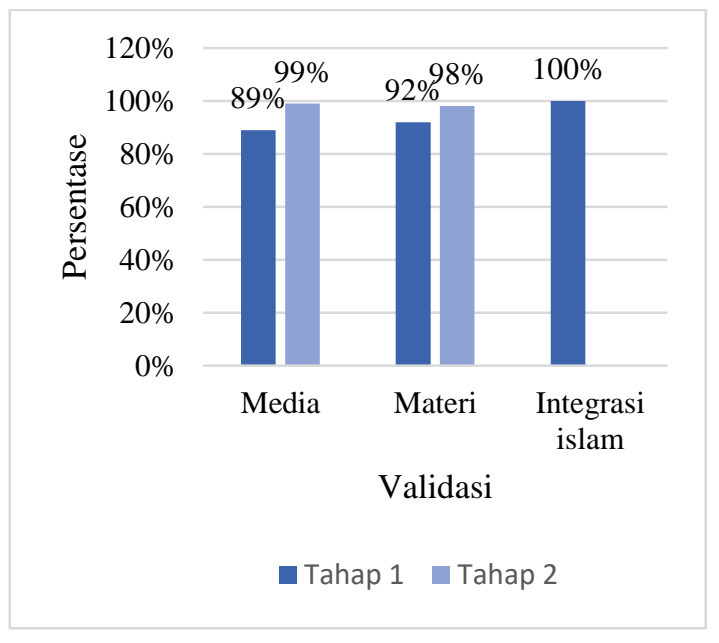

3. Pembahasan Tanggapan Guru dan Peserta Didik

Berdasarkan hasil wawancara yang dilakukan oleh peneliti kepada guru biologi MAN Kota Palangka Raya sebagai narasumber diketahui bahwa beliau belum pernah menggunakan media komik digital sebelumnya. Penggunaan video dalam kegiatan pembelajaran di kelas pernah dilakukan dan terlihat bahwa peserta didik tertarik dan lebih antusias dalam belajar. Akan tetapi, kegiatan seperti ini jarang dilakukan karena terbatasnya waktu dalam belajar di sekolah. Sehingga pembelajaran 


\section{JPSP: Jurnal Penelitian Sains dan Pendidikan}

https://e-journal.iain-palangkaraya.ac.id/index.php/mipa/

di kelas lebih sering ke arah metode konvensional atau penjelasan materi secara langsung oleh beliau saja. Tanggapan beliau sebagai seorang guru mengenai komik digital ini bahwa komik ini sudah sangat baik karena dapat digunakan oleh peserta didik dalam belajar mandiri. Beliau kembali mengungkapkan bahwa dengan adanya kelebihan komik digital ini yaitu termasuk media yang menyenangkan untuk pembelajaran yang diharapkan oleh beliau agar peserta didik dapat termotivasi untuk rajin belajar. Hal ini ternyata sesuai dengan hasil uji coba kelompok kecil dimana peserta didik dari aspek kemenarikan dan manfaat memberikan respon yang sangat baik. Selain itu, beliau juga mendukung komik digital ini karena memuat ayat-ayat Alquran yang terkait dengan Biologi karena MAN Kota Palangka Raya ini merupakan sekolah yang juga berbasis pondok pesantren. Untuk uraian nilai-nilai karakter islami, beliau juga beranggapan hal itu cukup bagus diinformasikan kepada peserta didik.

Selanjutnya, peneliti melakukan uji coba kepada peserta didik berupa kelompok kecil yang terdiri atas 6 orang peserta didik kelas X IPA. Penelitian dilakukan secara online dengan menggunakan smartphone masing-masing peserta didik. Penelitian secara online ini dilakukan karena komik digital ini memang dapat dirancang untuk dapat diakses secara online. Peneliti menjelaskan dan menyampaikan isi komik dalam lingkup diskusi menggunakan aplikasi WhatsApp. Hasil uji coba kelompok ini bahwa pada aspek materi diperoleh persentase sebesar 91,3\% dengan kriteria sangat baik dan layak untuk digunakan terlebih untuk penelitian tahap lanjut.

Tanggapan peserta didik pada uji coba kelompok kecil secara keseluruhan mendapat tanggapan baik. Hasil penelitian menunjukkan bahwa komik digital yang dikembangkan mendapat respon yang sangat baik dari peserta didik yang artinya peserta didik tertarik untuk belajar menggunakan media komik ini.

Hasil pengembangan menunjukkan bahwa komik yang dikembangkan mendapat respon yang sangat baik dari peserta didik yang artinya peserta didik tertarik untuk belajar menggunakan komik ini. Hasil penelitian ini selaras dengan penelitian sebelumnya yaitu penelitian oleh Resti Wahyu Danaswari (2019), Rocky Kalvadema (2017), dan Naily Irfana dkk. (2017) tentang pengembangan media komik yang mendapat respon positif. Kepraktisan media yang berbasis digital dapat memudahkan peserta didik dalam menggunakannya sehingga dapat digunakan dimana saja dan kapan saja, hal ini selaras dengan penelitian relevan dari Rida Dela Aprilia (2018) mengenai pengembangan media komik berbasis android. Kemudian hasil yang sama didapatkan pada penelitian Nisda Yunia (2017) bahwa dengan adanya penggalian nilai karakter dari materi dalam komik digital yang yang dibahas membuat peserta didik termotivasi dan merasakan pembelajaran yang telah dilakukan lebih 
https://e-journal.iain-palangkaraya.ac.id/index.php/mipa/

bermakna. Komik yang memuat materi integrasi nilai islam mendapatkan hasil yang positif dari peserta didik maupun validator.

\section{SIMPULAN}

Berdasarkan hasil penelitian pengembangan dengan judul "Pengembangan Media Komik Digital Materi Virus Terintegrasi Nilai Islam di MAN Kota Palangka Raya", maka dapat disimpulkan:

1. Profil komik digital hasil pengembangan ini yaitu berbasis Flip PDF yang dapat digunakan melalui laptop, komputer dan smartphone. Plot pada komik ini ada 3 bagian yaitu pembuka, materi (inti) dan penutup. Materi yang dimuat adalah materi biologi kelas $\mathrm{X}$ tentang virus berdasarkan silabus kurikulum 2013 serta pemaparan integrasi nilai islam serta informasi terkini mengenai materi.

2. Hasil validasi tahap akhir dan uji coba kelompok menggunakan komik digital yang telah dilakukan yaitu validasi ahli media diperoleh persentase $99 \%$ dengan katagori sangat baik dan sangat layak digunakan, validasi ahli materi diperoleh persentase $98 \%$ dengan kriteria sangat baik dan layak digunakan, validasi ahli materi integrasi islam diperoleh persentase $100 \%$ dengan kriteria sangat baik dan layak digunakan. Serta hasil uji skala kecil pada 6 peserta didik memperoleh persentase sebesar 91,3\% dengan kriteria sangat baik dan layak digunakan.
3. Hasil uji kepraktisan produk hasil pengembangan ini adalah sangat positif. Tanggapan guru mengenai produk hasil pengembangan bahwa komik digital ini sudah sangat baik karena dapat digunakan oleh peserta didik dalam belajar mandiri, memuat integrasi ayat Alquran tentang materi biologi virus serta menyisipkan unsur humor di dalamnya. Tanggapan peserta didik bahwa komik ini sangat bagus, mudah digunakan dimana saja, dan memotivasi untuk belajar.

4. Uji efektifitas pada kelompok kecil dilakukan dan didapat hasil persentase 91,3\% dengan katagori sangat baik.

\section{DAFTAR PUSTAKA}

Hasama, Setyaningrum Y. 2013. Desain Pembelajaran Berbasis Pencapaian Kompetensi (Panduan dalam Merancang Pembelajaran untuk Mendukung Implementasi Kurikulum 2013. Jakarta: Prestasi Pustaka Jakarta.

Irfana N, Iswari. 2017. Pengembangan Komik Digital "Let's Learn About Virus" Sebagai Media Pembelajaran Biologi Siswa Kelas X SMA". Journal of Biology Education. 6(3). 258-254 [jurnal Internasional]

Kalvadema R. 2017 “Artikel Ilmiah Pengembangan Media Pembelajaran Komik Kontekstual Pada Materi Virus Untuk Siswa SMA Kelas X MIPA”. Fakultas Keguruan dan Ilmu Pendidikan. Jurusan Pendidikan MIPA. Universitas Jambi. Jambi 
https://e-journal.iain-palangkaraya.ac.id/index.php/mipa/

Kemendikbud. 2018. Permendikbud No. 24

Tentang kompetensi Inti dan Kompetensi

Dasar Pelajaran Pada Kurikulum 2013

Pada Pendidikan Dasar Dan Menengah.

Jakarta: Kemendikbud

Mulyatiningsih E. 2012. Metode Penelitian

Terapan Bidang Pendidikan. Bandung:

Alfabeta

Mulyono Y., Sardimi S, Lestaringsih N. 2017.

Implementasi Kurikulum 2013 Mata

Pelajaran Biologi Terintegrasi Keislaman

di Madrasah Aliyah (MA): Model

Evaluasi Cippo, Jurnal Transformatif

(Islamic Studies). 1(2), 247-258

Aprilia RD. 2019. "Skripsi Pengembangan

Media Komik Pembelajaran Berbasis

Android Pada Materi Archaebacteria Dan

Eubacteria". Skripsi. Fakultas Tarbiyah

dan Ilmu Keguruan. Jurusan Pendidikan

MIPA. Universitas Islam Negri Raden

Intan Lampung. Lampung.

Sudjana N. 2010. Cara Belajar Siswa Aktif

dalam Proses Belajar Mengajar.

Bandung: Sinar Baru Algesindo

Sumiharsono R, Hasanah H. 2017. Media

pembelajaran. Jawa Timur: CV

Pustaka Abadi

Sugiyono. 2019. Metode Penelitian

Pendidikan. Bandung: Alfabeta.

Widaningsih I. 2019. Strategi dan Inovasi

Pembelajaran Bahasa Indonesia di Era

Revolusi Industri 4.0. Ponorogo: Uwais Inspirasi Indonesia.

Yunia N. 2017. Pengembangan Media

Pembelajaran Komik Digital Biologi

Berbasis Nilai Karakter Pada Materi
Pokok Sistem Pencernaan Makanan Untuk Kelas Viii Mts Negeri 1 Bandar Lampung. Skripsi. Fakultas Tarbiyah dan Keguruan. Institut Agama Islam Negeri (Iain) Raden Intan Lampung. Lampung 